\title{
Synthesis and Characterization of Trivalent Cerium Complexes of p-tert-Butylcalix[4,6,8]Arenes: Effect of Organic Solvents
}

\author{
Md. Hasan Zahir \\ Chemistry Department, King Fahd University of Petroleum and Minerals, Dhahran 31261, Saudi Arabia \\ Correspondence should be addressed to Md. Hasan Zahir; hzahir@kfupm.edu.sa
}

Received 6 December 2012; Accepted 22 January 2013

Academic Editor: Giuseppe Gattuso

Copyright (c) 2013 Md. Hasan Zahir. This is an open access article distributed under the Creative Commons Attribution License, which permits unrestricted use, distribution, and reproduction in any medium, provided the original work is properly cited.

\begin{abstract}
Reaction of $\mathrm{Ce}^{3+}$ with p-tert-butylcalix $[n]$ arene $(n=4,6,8)$ yields purple crystalline complexes structurally as $[\mathrm{Ce}(\mathrm{p}$-tertbutylcalix[4] arene-3H $\left.)_{2}\left(\mathrm{NO}_{3}\right)(\mathrm{DMF})_{x}\right](2-x) \operatorname{DMF}(\mathbf{1})$, [Ce(p-tert-butylcalix[6]arene-4H $\left.)_{2}\left(\mathrm{NO}_{3}\right)(\mathrm{DMF})_{x}\right](3-x) \mathrm{DMF}(2)$, and $\left[\mathrm{Ce}(\mathrm{p} \text {-tert-butylcalix [8] arene-7H })_{2}\left(\mathrm{NO}_{3}\right)(\mathrm{DMF})_{6}\right](3)$, where $\mathrm{DMF}=\mathrm{N}, \mathrm{N}$-dimethylformamide. The properties and coordination characteristics of the three calixarene complexes were determined by elemental analyses, electronic absorption, X-ray absorption spectroscopy (EXAFS), TG-DTA, FT-IR, SEM, and ${ }^{1} \mathrm{H}-\mathrm{NMR}$ spectroscopy. The effect of various organic solvents on complexes 1, 2 , and 3 has been discussed based on results from electronic absorption spectra. The polar protic solvents showed the most significant molar extinction coefficients in comparison with those of nonpolar and polar aprotic solvents. The $\mathrm{Ce}^{3+}$ ions in the complexes are proved to combine with the ligand phenolic groups, oxygen atoms of DMF molecules, and/or $\mathrm{OH}^{-}$ions.
\end{abstract}

\section{Introduction}

Calixarenes are macrocyclic compounds built of $n$ phenol linked via alkylidene groups in such a way that large cavities of molecular dimensions are formed [1]. These molecules, and their various substituted derivatives, make up one of the most important families of supramolecular chemistry [2]. From a coordination chemistry point of view, the parent unsubstituted calixarenes can be considered as large, flexible polyalkoxide ligands whose size and flexibility vary with the number of their phenolic units [3]. The interest and fascinating potential of this class of molecules for the design of new metal complexes are well illustrated by calix[6]arene, which has already been used for the synthesis of compounds containing one [4], two [5], three [6], and even five [6] metal cations. Moreover, the large calixarene p-t-butylcalix[8] arene is a ligand which can act as a ditopic receptor for the lanthanide and other [7] ions and hence in principle may bind in various ways to a single metal ion.

It has been reported that p-t-butylcalix[4]arene is able to form complexes with transition-metal ions in which its cup shape is preserved and, in some cases, include a solvent molecule within the cup [8]. The generation of a base to the cup by metal-ion coordination is analogous to the building of a "floor" into cyclodextrins [9] and might similarly be expected to modify the inclusion tendencies of the receptor. Indeed, if coordination to the metal ion through the cup were to be possible, considerable selectivity in inclusion complex formation might arise. Furphy et al. [10] reported that the europium(III) complex of p-t-butylcalix[4]arene does contain the ligand in its "cup" conformation and indeed does form an inclusion complex with dimethylformamide. The structures of europium(III) complexes of both $\mathrm{p}$ - $\mathrm{t}$ butylcalix[6]arene and p-t-butylcalix[8] arene [10] (where uncoordinated solvent inclusion is not observed) confirm the obvious assumption that the close proximity of calixarene substituents induced by the cone conformation of calix[4]arene is important for solvent inclusion and hence suggests that subtle control of inclusion may well be possible by modification of the cone conformation through metal coordination.

The donor properties of the calixarenes have long prompted the interest of coordination chemists in their search for new ligands well suited for the large and hard cations of the f-elements [11]. Although many examples of synthetic receptors showing unique complexing abilities 
toward metal cations are known, the research in this field is still very active with the aim of obtaining complexes showing new properties or improved selectivity. Izatt et al. reported [12] that calixarenes are capable of selective ion transport and the formation of neutral complexes with cations through proton loss. It has also been found that the hydroxyl and pyridyl groups possess large affinities for the rare earth ions; for example, Engelhardt et al. [4] have demonstrated the formation of both mono- and bimetallic lanthanide ion complexes of p-t-butylcalix[8] arene. Extensive studies on interactions of lanthanides and calixarene anions have been carried out by Bünzil et al. [13], and some very interesting chemistry has been reported by these authors. In contrast with lanthanidecalixarene complexes, $\mathrm{Ce}^{3+}$-calixarene complexes have rarely been synthesized and the coordination features of $\mathrm{Ce}^{3+}$ calixarene complexes are unknown. $\mathrm{A} \mathrm{Ce}^{3+}$ cation complex of p-tert-butylcalix[8] arene has been synthesized by the method described for the thorium(IV) complex, but unfortunately the deep purple complex of Ce-calixarene complexes consistently displays crystal morphologies unsuited to structure determination by X-ray diffraction [14]. Chawla et al. [15] reported a short note regarding the possible structures of $\left[\mathrm{Ce}_{2}(\right.$ calix $\left.[8]-8 \mathrm{H})(\mathrm{DMSO})_{5}\right] \cdot(\mathrm{DMSO})_{2}$ complex. Our literature search indicated that the coordination chemistry of calix $[n]$ arene as a ligand for the lanthanide family has not yet been investigated in detail. In fact the europium complex $\left[\mathrm{Eu}(\mathrm{H} 6 \mathrm{~L})(\mathrm{OH})(\mathrm{DMF})_{6}\right](\mathrm{H} 6 \mathrm{~L}=\mathrm{p}$-t-butylcalix[6]arene) is the only $4 \mathrm{f}$-metal complex of a calix[6]arene derivative whose crystal structure has been solved [16]. Moreover, the recognition of organic solvents by synthetic receptors is a topic of current interest in supramolecular [17] and analytical chemistry [18]. As reflected in the information provided in the literature [19], the thermodynamic origin of calix [ $n]$ arene complexes stability is known for a few systems in a limited number of solvents. In addition, the physical properties and the effect of organic solvents over lanthanide-calixarene complexes have not been investigated in detail.

Recently, $\mathrm{Ce}^{4+}$ cation complex of p-tertbutylcalix $[n]$ arene $(n=4,6,8)$ has been synthesized by Zhang et al. [20]. However, it was not clear that Zhang et al. really obtained a Ce(IV) coordination compound but they probably synthesized $\mathrm{Ce}(\mathrm{III})$ instead. In fact, they were working with $\mathrm{Ce}\left(\mathrm{NO}_{3}\right)_{3}$ which means $\mathrm{Ce}(\mathrm{III})$. In this study, thermal stability, optical properties, and coordination features were characterized. We also concentrated on the complexation between $\mathrm{Ce}^{3+}$ and p-tert-butylcalix $[n]$ arenes ( $n=4,6,8)$ in order to extend the calixarene complexing reactions to $\mathrm{Ce}^{3+}$, in an attempt to understand the important properties of $\mathrm{Ce}^{3+}$-calixarene compounds. In addition, the effects of polar protic, polar aprotic, and nonpolar solvents on the synthesized three $\mathrm{Ce}^{3+}$-calixarene complexes were studied.

\section{Experimental Section}

2.1. Chemicals. p-t-butylcalix[4]arene (Ligand-1), p-tbutylcalix[6] arene (Ligand-2), and p-t-butylcalix[8] arene (Ligand-3) were purchased from Aldrich and used without

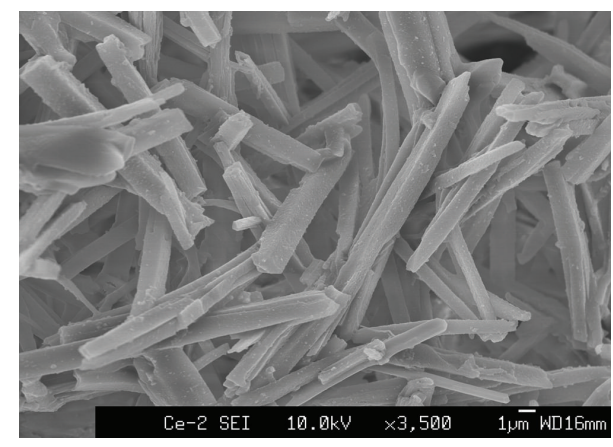

FIGURE 1: Typical SEM images of complex 2 powder after recrystallization from acetone-acetonitrile organic solvents.

further purification. $\mathrm{Ce}\left(\mathrm{NO}_{3}\right)_{3} \cdot 6 \mathrm{H}_{2} \mathrm{O}$ was also obtained from Aldrich. All the chemicals were used as received.

2.2. Preparation. A thin semiliquid solution was prepared adding dimethylformamide (DMF, $10 \mathrm{~mL}$ ) into $\mathrm{p}$-tbutylcalix[4]arene, p-t-butylcalix[6]arene, and p-tbutylcalix[8]arene. This slurry solution was heated to $60^{\circ} \mathrm{C}$ and triethylamine $(0.6 \mathrm{~mL})$ was added drop by drop until a clear, colorless solution formed. In case of complex 1 formation, $0.8 \mathrm{~mL}$ triethylamine was added. Then a solution of $\mathrm{Ce}\left(\mathrm{NO}_{3}\right)_{3} \cdot \mathrm{DMSO}(0.06 \mathrm{~g})$ was added quickly with the ligand solution. The $\mathrm{Ce}\left(\mathrm{NO}_{3}\right)_{3}(\mathrm{DMSO})_{n}$ solvates were synthesized according to the literature method [13]. A deep purple solution for $\mathrm{Ce}^{+}$-p-t-butylcalix[6]arene (complex 2) and $\mathrm{Ce}^{3+}$-p-t-butylcalix[8]arene (complex 3) and pale purple solution for $\mathrm{Ce}^{3+}$-p-t-butylcalix[4] arene (complex 1) were obtained. After cooling in an ice bath, the solution was kept for $24 \mathrm{~h}$ at $4^{\circ} \mathrm{C}$; subsequently amorphous precipitates were obtained. Then the solution was filtered (with no. 5C filter paper); the filtrate dried by vacuum desiccation showed weak efflorescence and became opaque. Finally, on recrystallisation from acetone $(50 \mathrm{~mL})$, acetonitrile $(50 \mathrm{~mL})$ with complexes gave deep purple crystals in approximately $30 \%$ yield in case of $\mathbf{1}$ and $60 \%$ in case of $\mathbf{2}$ and pale purple crystals in approximately $40 \%$ yield, in case of 3 . Figure 1 shows the typical SEM images of recrystallized powder (complex 2) from acetone-acetonitrile solvents. A rod-like morphology was observed for complex 2 with a diameter, length, and aspect ratio in the range of $0.1-10,100-300$, and $40-90 \mu \mathrm{m}$, respectively. Although the structural change of $\mathbf{2}$ upon mixing with acetone-acetonitrile molecules is insignificant as observed by FT-IR spectra (figure is not shown) however, the morphology shows rod-like particles in comparison with those of parent ligand 2 . It is noteworthy that this is the first article to report SEM morphology of $\mathrm{Ce}^{3+}$-p-t-butylcalix[6]arene complex after recrystallisation from acetone-acetonitrile solvents.

The elemental analytical results are as follows: found: C, 72.77; H, 8.67; N, 1.68; requires $\mathrm{C}, 72.83 ; \mathrm{H}, 7.90 ; \mathrm{N}$, 1.70 in case of complex 1 [Ce(p-tert-butylcalix[4]arene$\left.3 \mathrm{H})_{2}\left(\mathrm{NO}_{3}\right)(\mathrm{DMF})_{x}\right](2-x) \mathrm{DMF}, \quad$ found: $\mathrm{C}$, 66.23; $\mathrm{H}, 7.28 ; \mathrm{N}, 3.87$; requires $\mathrm{C}, 67.07 ; \mathrm{H}, 7.9 ; \mathrm{N}, 3.82$ 
in case of complex 2 [Ce(p-tert-butylcalix[6] arene$\left.4 \mathrm{H})_{2}\left(\mathrm{NO}_{3}\right)(\mathrm{DMF})_{x}\right](3-x) \mathrm{DMF}$, found: $\mathrm{C}, 64.13 ; \mathrm{H}, 7.23 ; \mathrm{N}$, 3.17; requires C, 63.97; H, 7.63; N, 2.24 in case of complex 3 $\left[\mathrm{Ce}(\mathrm{p} \text {-tert-butylcalix [8] arene- } 7 \mathrm{H})_{2}\left(\mathrm{NO}_{3}\right)(\mathrm{DMF})_{6}\right]$.

2.3. Instruments. Electronic absorption spectra were measured by a Shimadzu self-recording spectrophotometer (Model 240) with $10 \mathrm{~mm}$ optical path quartz cells. ${ }^{1} \mathrm{H}-\mathrm{NMR}$ data were recorded on a JEOL JNM-GX 61D FT-NMR spectrometer operating at $400 \mathrm{MHz}$ in $\mathrm{CDCl}_{3}$, using TMS as internal standard. TG-DTA curves were obtained with a Rigaku Thermo Plus DTA and TG 8120 analyzer, under air from room temperature to $700^{\circ} \mathrm{C} . \mathrm{Al}_{2} \mathrm{O}_{3}$ was used as reference and the temperature was increased at a rate of $3^{\circ} \mathrm{C} \mathrm{min}^{-1}$. Elemental $\mathrm{C}, \mathrm{H}$, and $\mathrm{N}$ analyses were carried out with Perkin-Elmer model 240 automatic equipment. Infrared spectra were recorded with a Perkin Elmer FTIR spectrometer (Spectrum 1000) by a diffusion reflectance method (KBr media). Morphology of the product particles was examined using scanning electron microscopy (SEM, JEOL JSM6330F).

2.4. Spectral Characteristics and Procedure. The cerium ion concentration in the solutions was adjusted so that the maximum value of $\log I_{o} / I$ lay between 1 and 2 . The measurements were made by first filling the cells with solvents and obtaining a "blank" tracing over the desired spectral region. The solvent in one of the cells was then replaced by the complex solution to be measured and a second tracing obtained over the same region. The absolute value of $\log I_{o} / I$ at any given wavelength could be obtained directly from the difference in height of the two tracings. In making up these solutions, $1 \mathrm{~mL}$ of concentration $\left(1.3 \times 10^{-6} \mathrm{M}\right),\left(1.2 \times 10^{-6} \mathrm{M}\right)$ and $\left(1.2 \times 10^{-6} \mathrm{M}\right)$ of complexes 1,2 , and 3 , respectively, were taken in a $20 \mathrm{~mL}$ volumetric flask and made up to volume with the appropriate solvent. The volumetric apparatus was calibrated in the usual way by weighing the volume of distilled water needed to fill the apparatus to the mark. All solutions were freshly prepared, directly before making absorption measurements.

2.5. Determination of Metal Ion Concentration in the Complex. $1 \mathrm{~mL}$ solution was decomposed by $1 \mathrm{~mL}$ conc. $\mathrm{HNO}_{3}$ and $2 \mathrm{~mL}$ $\mathrm{HClO}_{4}$ and then the amount of cerium present in the complex solution were computed from the predetermined calibration plot according to the method using arsenazo(III) [21].

2.6. EXAFS Measurements. EXAFS spectra were measured around the $\mathrm{Ce}-\mathrm{K}$ edge in transmission mode using the $\mathrm{BL}$ 7C station at Photon Factory of the National Laboratory for High Energy Physics (Tsukuba, Japan). A broad band synchrotron radiation was monochromatized by a $\mathrm{Si}(111)$ channel-cut crystal. The electron storage ring was operated at $2.5 \mathrm{GeV}$ with a beam current of $335.0 \mathrm{~mA}$. The measurements were performed at room temperature. Sample solutions were held in a 3 or $5 \mathrm{~mm}$ thick Teflon cell with polyethylene windows and the cell was placed between the first and the second ionization chambers. The apparent absorbance was

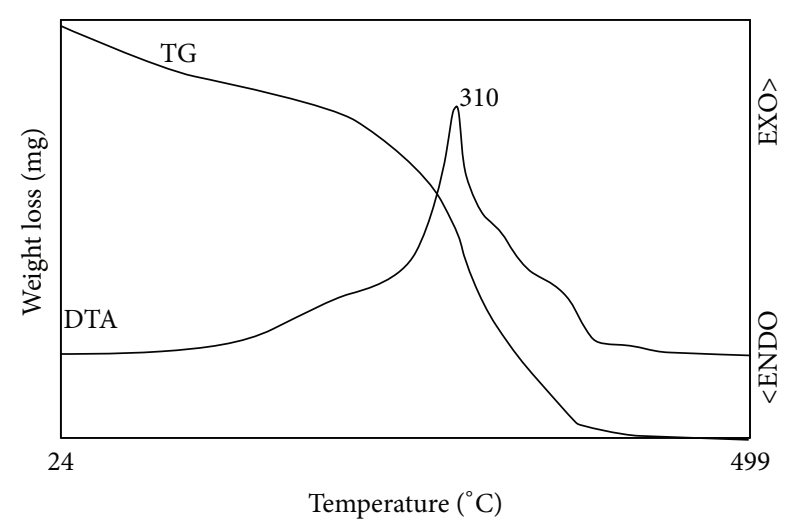

Figure 2: Thermogravimetric analytical curves of $\mathrm{Ce}^{3+}-\mathrm{p}-\mathrm{t}-$ butylcalix[6] arene complex. Sample weight: $12.40 \mathrm{mg}$.

obtained as in $\left(I_{o} / I\right)$, where $I_{o}$ and I are X-ray intensities with and without a sample, respectively. Intensities II and I were simultaneously measured by the first and the second ionization chambers, respectively. The first ionization chamber was filled with $\mathrm{N}_{2}$ and $\mathrm{N}_{2}+\mathrm{He}(30 \%)$ gas in the Ce$\mathrm{K}$ edges and the second one with $\mathrm{N}_{2}(85 \%)+\mathrm{Ar}(15 \%)$ and Ar gas in the corresponding edges. EXAFS data analyses were performed by computer PC-9801 RA. A curve fitting procedure in the $k$ space for the refinements of structure parameters was applied to the Fourier filtered $\kappa^{3} \cdot \chi(\kappa)_{\text {obsd }}$ values to minimize $\sum \kappa^{6} \cdot\left(\chi(\kappa)_{\text {obsd }}-\chi(\kappa)_{\text {calcd }}\right)^{2}$.

\section{Results and Discussion}

3.1. Thermogravimetric Analysis. The thermogram of the three complexes exhibited similar mass loss profile below $200^{\circ} \mathrm{C}$. The mass loss which takes place below $200^{\circ} \mathrm{C}$ is probably due to the physical desorption of water and the evaporation of organic compound. From the TG-DTA curves of complex 1, it has been observed that there are three major weight losses of $14.30 \%, 2.40 \%$, and $42.12 \%$ for this complex. Abrupt decomposition was not observed in this case. The huge loss of weight was located in between 330 and $447^{\circ} \mathrm{C}$. After this, further weight loss of $7.09 \%$ was found to be up to temperature $550^{\circ} \mathrm{C}$. A dehydrates at ca. $90^{\circ} \mathrm{C}$, successively loses four DMF molecules by two steps in the temperature range of $97-277^{\circ} \mathrm{C}$, with a sharp exothermic peak. The sharpest exothermic peak is located in between 380 and $410^{\circ} \mathrm{C}$ and very close to $385.7^{\circ} \mathrm{C}$. A weak exothermic peak in the last step of the decomposition was close to $500^{\circ} \mathrm{C}$.

In the case of complex 2, there are two major weight losses of $10.15 \%$ and $60.11 \%$ observed (Figure 2 ). The second decomposition abruptly begins to take place accompanied by a huge loss of weight up to a temperature close to $343^{\circ} \mathrm{C}$. From this temperature onwards and up to $450^{\circ} \mathrm{C}$, the loss of mass is very slow after which their mass remains stable until the maximum heating temperature of $499^{\circ} \mathrm{C}$. First weight loss is due to the dehydration of water and nitrate decomposition and the latter corresponds to the thermal decomposition of organics with the simultaneous formation 
of amorphous complex. In the case of complex 2, the DTA curve shows that a first peak was endothermic; minimum appears within a temperature range of $23-50^{\circ} \mathrm{C}$. A second exothermic peak is located in between 250 and $350^{\circ} \mathrm{C}$, with a maximum in the $280-310^{\circ} \mathrm{C}$ range, and corresponds to the rapid decomposition of the complexes, the third peak with one shoulder; also exothermic is located between 340 and $380^{\circ} \mathrm{C}$. The weight losses between 23 and $148^{\circ} \mathrm{C}$ correspond to the water molecules and nitrate ion for the complexes. Because of low temperatures, such water molecules can be considered as crystal water molecules. The complexes undergo decomposition at ca. $150^{\circ} \mathrm{C}$.

In the case of complex 3 , it has been observed that there are two major weight losses of $12.23 \%$ and $57.53 \%$. The second decomposition abruptly begins to take place accompanied by a huge loss of weight up to a temperature close to $381^{\circ} \mathrm{C}$. From this temperature onwards and up to $445^{\circ} \mathrm{C}$ the loss of mass is very slow after which their mass remains stable until the maximum heating temperature of $500^{\circ} \mathrm{C}$. The process of the thermal decomposition of each sample may be considered to take place in one of the following ways. The DTA diagram shows a first shoulder peak, which was exothermic and whose minimum appears within a temperature range of $200-250^{\circ} \mathrm{C}$. A second exothermic peak is located in between 300 and $400^{\circ} \mathrm{C}$, with a maximum in the $355^{\circ} \mathrm{C}$. All complexes liberated all adhesive moisture, water molecule, and crystal water molecules after 15 min heating.

3.2. Solubilities. Insolubility in water and aqueous base and their low solubility in organic solvents left some of the calix $[n]$ arenes very difficult to isolate, to purify, and to characterize [19]. Fortunately complexes $\mathbf{1}, \mathbf{2}$, and $\mathbf{3}$ are soluble in various organic solvents; however, the complexes are insoluble in Triton-X and dioctyl sebacate organic solvents for a satisfactory spectrum to be obtained. Although metal compounds containing the larger ring system (p-tbutylcalix [8]arene) is scant, however Bünzil et al. reported that the lanthanides complexes with p-t-butylcalix[8]arene are organic-solvent soluble, suggesting that it might be used in solvent extraction and purification of the lanthanides [13]. It is important to note that the parent p-t-butyl-calix $[n]$ arenes are not dissolved in xylene; however, the $\mathbf{1}, \mathbf{2}$, and $\mathbf{3}$ complexes are fully soluble in xylene. Moreover, an opaque solution was formed upon the addition of three complexes into the dioctyl phthalate and methyl isobutyl ketone solvents.

3.3. Characterization of Electronic Absorption Spectra. The spectra of the complexes show wavelengths of absorbance lying at $280-290 \mathrm{~nm}$, which are also observable for the corresponding parent ligands [22]. It has been reported that the complex formation is noticeable in the case of $\mathrm{Eu}(\mathrm{III})$, when its solution color was orange. This is related to the presence of a low-energy ligand-to-metal charge-transfer state (LMCT) lying at $256 \mathrm{~nm}$ [13]. In this study, we have observed different colors of the synthesized complexes in various solvents which are favourable to observe the solvent effect by UV-Vis spectrophotometer. The electronic absorption spectra of $\mathbf{1 , 2}$, and $\mathbf{3}$ complexes in organic solvents are shown in Figure 3.
Gutsche et al. [22] reported that the shortest transannular distance between the surfaces of the oxygen atoms is ca. $0.8 \AA$ in the cyclic tetramer (p-t-butylcalix[4]arene) and ca. 2.0-2.9 $\AA$ in the cyclic octamer (p-t-butylcalix[8] arene). The cyclic tetramer is a rigid molecule, and there is very little possibility for variation in the diameter of the opening that is established on the bottom of the molecule by the cyclic array of hydroxyl groups. The cyclic hexamer ( $\mathrm{p}$ t-butylcalix[6]arene), however, is moderately flexible and appears to be capable of establishing openings anywhere between 2.0 and $2.9 \AA$ in diameter. The cyclic octamer is very flexible, and in its most expanded conformation it has an opening of $4.5 \AA$ or more in diameter. Thus, the cyclic hexamer does indeed seem to be the oligomer most capable of encompassing a metal cation. This phenomenon was proved in our study from observing the molar extinction coefficients increase in the order of $6.59 \times 10^{4} \mathrm{~mol}^{-1} \mathrm{dm}^{2}>6.40 \times$ $10^{4} \mathrm{~mol}^{-1} \mathrm{dm}^{2}>5.59 \times 10^{4} \mathrm{~mol}^{-1} \mathrm{dm}^{2}$ for complexes 2,3 , and 1 , respectively.

The tested sixteen organic solvents showed a broad absorption feature in the wavelength range of 300-600 nm. The most significant effect was observed in methyl and ethyl alcohol, which may be attributed to the interaction of these solvents through aromatic proton and/or hydroxyl group of the ligand. No detailed spectral study, however, has been carried out on the calix $[n]$ arene of $\mathrm{Ce}^{3+}$ for which one could anticipate electron-transfer transitions and/or $4 \mathrm{f} \rightarrow 5 \mathrm{~d}$ intershell transitions in the visible or near-UV regions [1]. The broad absorption feature in the wide absorption range might be ascribed to the overlapping of intraligand $\pi^{*} \rightarrow \pi$ transition, intershell 5d $\rightarrow$ 4f transition, and LMCT (low energy ligand-to-metal charge transfer state) bands of cerium ions in the solvents. In fact, the absorption peak intensity of complexes increased particularly in methyl and ethyl alcohols than those of other tested solvents and their absorption maxima was observed at ca. 420 and $490 \mathrm{~nm}$ as shown in Figure 3. Moreover, Figures 3(a), 3(b), and 3(c) also show that the broad absorption maxima in methyl alcohol were shifted slightly toward shorter wavelength than those of ethyl alcohol. In the case of complex $\mathbf{2}$ (Figure 3(b)) and complex $\mathbf{3}$ (Figure 3(c)), the absorption peak intensity of methyl as well ethyl alcohol is higher than those of other tested solvents; however, in the case of complex $\mathbf{1}$, all the absorption peak intensities were slightly higher at around $470 \mathrm{~nm}$.

The results suggest that the complexes make coordination mainly in the polar protic organic solvents. In fact, the molar extinction coefficients of all tested polar protic solvents were comparatively higher than those of polar aprotic and nonpolar solvents. However, the case of methyl isobutyl ketone which is a polar protic solvent showed quite low absorption maxima as shown in Table 1.

The absorption maximum was very low in the case of nonpolar $\mathrm{CCl}_{4}$ solvent. In general, complexes 1, 2, and 3 showed lower absorption maxima when nonpolar solvents were used. The reason is not fully understood; however, it has been reported that lanthanide complexes of $\mathrm{p}$-tbutylcalix[8]arene in nonpolar solvents are extremely sensitive to exposure to the atmosphere [23]. The absorption 


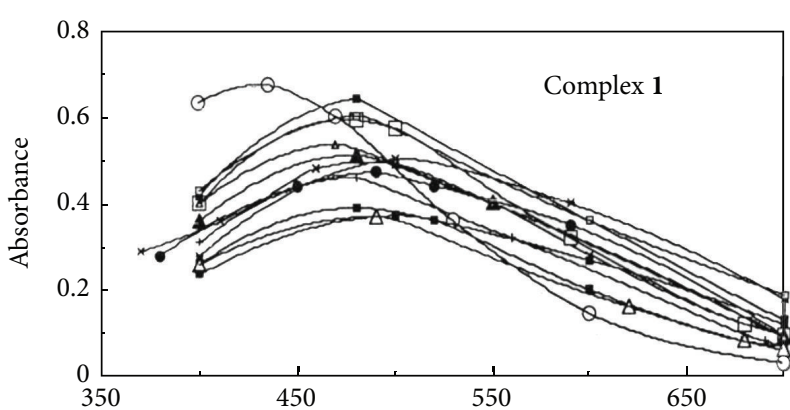

(a)

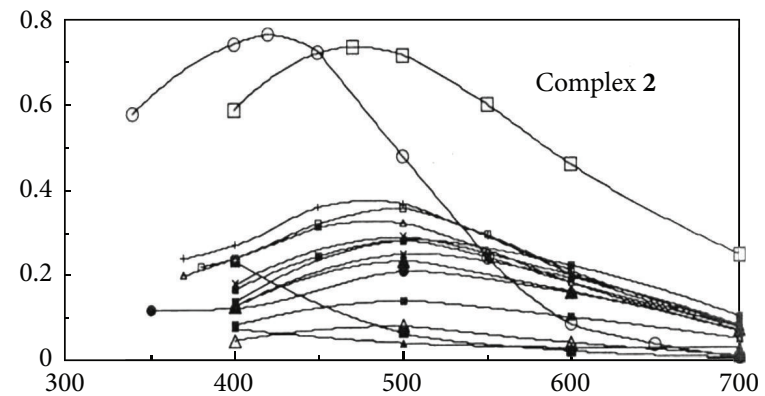

(b)

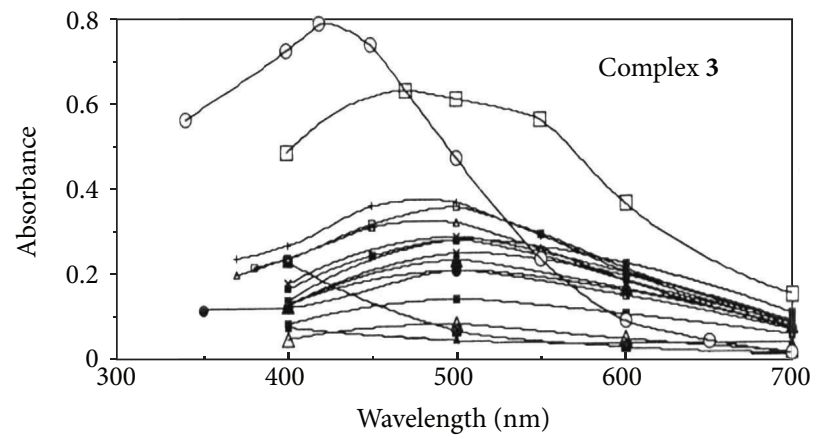

$\begin{array}{ll}{ }_{1} \text { Methyl alcohol } & \text { Benzene } \\ \triangle \text { Hexamethylphosphoric triamide } & + \text { n-propanol } \\ \text { 口 Dioctyl phthalate } & \square \text { Ethyl alcohol } \\ \text { Methyl isobutyl ketone } & \times \text { Benzonitrile } \\ \text { n-amyl alcohol } & * \text { 1-4 dioxane } \\ \square \text { n-butyl alcohol } & \text { Chloroform } \\ \Delta \text { Carbon tetrachloride } & \text { Acetone } \\ \triangle \text { Acetonitrile } & \text { Dimethyl sulfoxide }\end{array}$

(c)

FIgURE 3: Absorption spectra of (a) complex 1, (b) complex 2, and (c) complex 3 in various organic solvents; $\left[\mathrm{Ce}^{3+}\right]=1.3 \times 10^{-6} \mathrm{M}$, computed from the predetermined calibration plot.

increasing order in various solvents is as follows, that is, carbontetrachloride < methyl isobutyl ketone $<$ hexamethylphosphoric triamide $<$ chloroform $<$ n-amyl alcohol $<$ n-butyl alcohol and so on (Figure 3). The computed molar extinction coefficient values with the $\lambda_{\max }$ are listed in Table 1 . The scale of the extinction coefficient has been compressed tenfold between $1 \times 10^{4}$ and $6 \times 10^{4}$, in the range 400 $500 \mathrm{~nm}$. Methyl alcohol which exhibits large absorption on the long wavelength also gives a noticeable value $(6.07 \times$ $\left.10^{4}\right)$, and it can be presumed that such a value may indicate the interaction between the hydroxyl group of alcohol and the coordination compounds. One possible explanation is that the complexation of methyl alcohol is favoured because inclusion of the small methyl group inside the large cavities of the macrocyclic arrangement would lead to a partial inclusion of the polar $\mathrm{OH}$ group, which might enhance the polar hydroxyl group to be exposed to the polar solvent.

3.4. Analysis of FT-IR Spectra. In the IR spectra of the complexes, the intensities or wave numbers of the stretching vibration of the $\mathrm{OH}$ groups change drastically with complexation by breakage of the especially strong intramolecular hydrogen bonding existing in the free ligands [1]. For instance, in the case of $\mathbf{1},{ }^{v}(\mathrm{OH})$ is shifted by $24 \mathrm{~cm}^{-1}$ from 3168 to $3192 \mathrm{~cm}^{-1}$. So, the changes in the $v(\mathrm{O}-\mathrm{H})$ absorbance indicate that some hydroxide groups are deprotonated and coordinated to $\mathrm{Ce}^{3+}$ ions. The observed frequencies for $\mathbf{1}, \mathbf{2}$, and $\mathbf{3}$ along with their parent ligands are listed in Table 2. The associated nature of $\mathrm{C}\left(\mathrm{CH}_{3}\right)_{3},-\mathrm{CH}_{2}-$ and of the hydroxyl group have been reported previously [24]. The band $\mathrm{C}\left(\mathrm{CH}_{3}\right)_{3}$ gives a sharp absorption band at ca. $2960 \mathrm{~cm}^{-1}$, and this peak position was not shifted after making a complex with $\mathrm{Ce}^{3+}$ cation. It is important to note that this phenomenon was also observed for the complexes 1, 2, and 3. In the fingerprint region, the parent calixarenes all look rather similar to one another especially 1500 and $900 \mathrm{~cm}^{-1}$ wave numbers. In the $500-900 \mathrm{~cm}^{-1}$ region, however, the patterns vary to some extent $[1,22]$. The alkyl ethers of the p-t-butylcalix[4]arene and p-t-butylcalix[6]arene have strong absorption at $850 \mathrm{~cm}^{-1}$ and $810 \mathrm{~cm}^{-1}$ respectively. 
TABLE 1: Computed molar extinction coefficients of complexes 1, 2, and $\mathbf{3}$ in various organic solvents at $25^{\circ} \mathrm{C}$.

\begin{tabular}{|c|c|c|c|}
\hline Organic solvent & $\mathbf{1}\left(10^{4} \mathrm{~mol}^{-1} \mathrm{dm}^{2}\right)$ & $2\left(10^{4} \mathrm{~mol}^{-1} \mathrm{dm}^{2}\right)$ & $3\left(10^{4} \mathrm{~mol}^{-1} \mathrm{dm}^{2}\right)$ \\
\hline \multicolumn{4}{|l|}{ Polar protic } \\
\hline Methyl alcohol & 5.59 & 6.59 & 6.40 \\
\hline Ethyl alcohol & 5.11 & 6.07 & 5.87 \\
\hline n-Amyl alcohol & 4.27 & 2.34 & 2.10 \\
\hline n-Butyl alcohol & 4.00 & 3.00 & 2.90 \\
\hline n-Propanol & 3.10 & 2.65 & 2.40 \\
\hline Methyl isobutyl ketone & 0.80 & 0.50 & 0.50 \\
\hline \multicolumn{4}{|l|}{ Polar aprotic } \\
\hline Acetonitrile & 3.54 & 2.67 & 2.57 \\
\hline Hexamethylphosphoric triamide & 2.47 & 0.67 & 0.59 \\
\hline Dimethyl sulfoxide & 3.14 & 1.70 & 1.60 \\
\hline Acetone & 3.40 & 1.90 & 1.80 \\
\hline 1-4 Dioxane & 2.00 & 2.04 & 1.99 \\
\hline \multicolumn{4}{|l|}{ Nonpolar } \\
\hline Benzene & 2.47 & 1.87 & 1.77 \\
\hline Chloroform & 2.60 & 1.74 & 1.74 \\
\hline Carbon tetrachloride & 0.42 & 0.34 & 0.32 \\
\hline \multicolumn{4}{|l|}{ Other solvents } \\
\hline Benzonitrile & 2.14 & 1.89 & 1.79 \\
\hline Dioctyl phthalate & 1.00 & 0.86 & 0.75 \\
\hline
\end{tabular}

TABLE 2: Observed FT-IR bands of the synthesized complexes at $25^{\circ} \mathrm{C}$.

\begin{tabular}{|c|c|c|c|c|c|c|c|}
\hline \multirow{2}{*}{ Sample } & \multicolumn{7}{|c|}{ Wavelength in $\mathrm{cm}^{-1}$} \\
\hline & $v(\mathrm{OH})$ & $\mathrm{C}\left(\mathrm{CH}_{3}\right)_{3}$ & $-\mathrm{CH}_{2}-$ & $v(\mathrm{C}-\mathrm{OH})$ & $\nu(\mathrm{C}=\mathrm{C})$ & $\delta(\mathrm{C}-\mathrm{H})$ & $\mathrm{CH}_{3}$ wagging \\
\hline \multirow[t]{2}{*}{ Ligand-1 } & $3168(\mathrm{sb})$ & $2960(\mathrm{~s})$ & 2908 (vwsh) & $1200(\mathrm{~s})$ & $1484(\mathrm{w})$ & $872(w)$ & $964(\mathrm{w})$ \\
\hline & & & 2872 (vwsh) & $1364(\mathrm{w})$ & $1608(w)$ & & \\
\hline \multirow[t]{2}{*}{ Complex 1} & $3192(\mathrm{sb})$ & $2960(\mathrm{~s})$ & - & $1202(\mathrm{~s})$ & $1484(\mathrm{w})$ & $872(w)$ & $964(w)$ \\
\hline & & & 2872 (vwsh) & $1306(\mathrm{~s})$ & $1652(\mathrm{w})$ & & \\
\hline \multirow[t]{3}{*}{ Ligand-2 } & 3152 (vsb) & $2960(\mathrm{~s})$ & 2908 (vwsh) & 1204 (vs) & 1486 (vs) & $874(\mathrm{w})$ & $912(\mathrm{~m})$ \\
\hline & & & 2872(vwsh) & $1209(\mathrm{~s})$ & $1608(w)$ & & \\
\hline & & & & $1364(\mathrm{~s})$ & & & \\
\hline \multirow[t]{2}{*}{ Complex 2} & $3428(\mathrm{mb})$ & $2960(\mathrm{~s})$ & - & $1204(w)$ & $1490(\mathrm{~s})$ & $872(\mathrm{w})$ & $910(\mathrm{vw})$ \\
\hline & & & 2872 (vwsh) & $1364(\mathrm{vw})$ & $1614(\mathrm{~s})$ & & \\
\hline \multirow[t]{2}{*}{ Ligand-3 } & $3232(\mathrm{sb})$ & $2960(\mathrm{~s})$ & 2908 (vwsh) & 1204 (vs) & $1488(\mathrm{~s})$ & $874(w)$ & $914(\mathrm{w})$ \\
\hline & & & 2872 (vwsh) & $1364(w)$ & $1604(\mathrm{~s})$ & & \\
\hline \multirow[t]{2}{*}{ Complex 3} & $3408(\mathrm{sb})$ & $2960(\mathrm{~s})$ & - & $1208(\mathrm{vw})$ & $1462(\mathrm{w})$ & $872(w)$ & $964(w)$ \\
\hline & & & - & $1386(\mathrm{~m})$ & $1604(\mathrm{~s})$ & & \\
\hline
\end{tabular}

sh: shoulder, w: weak, m: medium, s: strong, v: very, b: broad.

Upon complexation with $\mathrm{Ce}^{3+}$ cation, the changes in the band frequencies of the complex in contrast with parent $\mathrm{p}$ - $\mathrm{t}-$ butylcalix[6] arene are the $-\mathrm{CH}_{2}-$ vibration at $2908 \mathrm{~cm}^{-1}$ and $1290 \mathrm{~cm}^{-1}$ were disappeared and also the peaks of phenolic hydroxyl-group vibrations at $1204 \mathrm{~cm}^{-1}$ and $1364 \mathrm{~cm}^{-1}$ were very low for complex 2 . The $v(\mathrm{C}=\mathrm{C})$ vibration bands shift by about $4 \mathrm{~cm}^{-1}$ toward higher frequencies for complex 2 . In the case of complex 3 , we have also observed that the $-\mathrm{CH}_{2}-$ vibrations disappeared fully and phenolic hydroxyl vibration was getting very weak and the very strong vibration at $1204 \mathrm{~cm}^{-1}$ disappeared. The differences in the infrared spectra may be caused by hydrogen bonding. The disappearance of plural phenolic hydroxyl group suggests that the metal ion has coordinated with phenolic oxygen by replacing its hydrogen.

3.5. Assignment of ${ }^{1} H-N M R$ Chemical Shift. The solution behavior of the complexes was determined by ${ }^{1} \mathrm{H}-\mathrm{NMR}$ spectroscopy in $\mathrm{CDCl}_{3}$ at room temperature. In the spectra 
TABLE 3: ${ }^{1} \mathrm{H}-\mathrm{NMR}$ spectra of the parent ligands and their $\mathrm{Ce}^{3+}$-p-t-butylcalix $[n]$ arene $(n=4,6$ and 8$)$ complexes at $25^{\circ} \mathrm{C}$.

\begin{tabular}{|c|c|c|c|c|c|c|}
\hline & Solvent & Complex pattern & $\mathrm{Ar}-\mathrm{C}\left(\mathrm{CH}_{3}\right)_{3}$ & $\mathrm{Ar}-\mathrm{CH}_{2}-\mathrm{Ar}$ & $\mathrm{Ar}-\mathrm{H}$ & $\mathrm{Ar}-\mathrm{OH}$ \\
\hline \multirow[t]{2}{*}{ Ligand-1 } & $\mathrm{CDCl}_{3}$ & & $1.26(\mathrm{~s}, 9)$ & 4.1 (br.d, 1) & $7.08(\mathrm{~s}, 2)$ & $9.6(\mathrm{~s}, 1)$ \\
\hline & & & & 3.1 (br.d, 1) & & \\
\hline \multirow[t]{2}{*}{ Complex 1} & & $3.10(\mathrm{br}, 1)$ & $1.25(\mathrm{~s}, 9)$ & 4.3 (br.d, 1) & $7.12(\mathrm{~s}, 2)$ & $10.4(\mathrm{~s}, 1)$ \\
\hline & & & & 3.8 (br.d, 1) & & \\
\hline Ligand-2 & $\mathrm{CDCl}_{3}$ & & $1.25(\mathrm{~s}, 9)$ & $3.77(\mathrm{~d}, 1)$ & $7.08(\mathrm{~s}, 2)$ & $10.0(\mathrm{~s}, 1)$ \\
\hline \multirow[t]{2}{*}{ Complex 2} & & $2.57(s, 1)$ & $1.26(\mathrm{~s}, 9)$ & $3.89(\mathrm{~s}, 2)$ & $7.14(\mathrm{~s}, 2)$ & $10.3(\mathrm{~s}, 1)$ \\
\hline & & $3.00(\mathrm{~d}, 1)$ & & & & \\
\hline Ligand-3 & $\mathrm{CDCl}_{3}$ & & $1.24(\mathrm{~s}, 9)$ & $4.3(\mathrm{br}, \mathrm{d}, 1)$ & $7.10(\mathrm{~s}, 2)$ & $9.6(s, 1)$ \\
\hline \multirow[t]{2}{*}{ Complex 3} & & $3.00(s, 1)$ & $1.27(\mathrm{~s}, 9)$ & $4.3(\mathrm{br}, \mathrm{d}, 1)$ & $7.14(\mathrm{~s}, 2)$ & $10.3(\mathrm{~s}, 1)$ \\
\hline & & & & $3.4(\mathrm{br}, \mathrm{d}, 1)$ & & \\
\hline
\end{tabular}

s: singlet, br: broad, d: doublet.

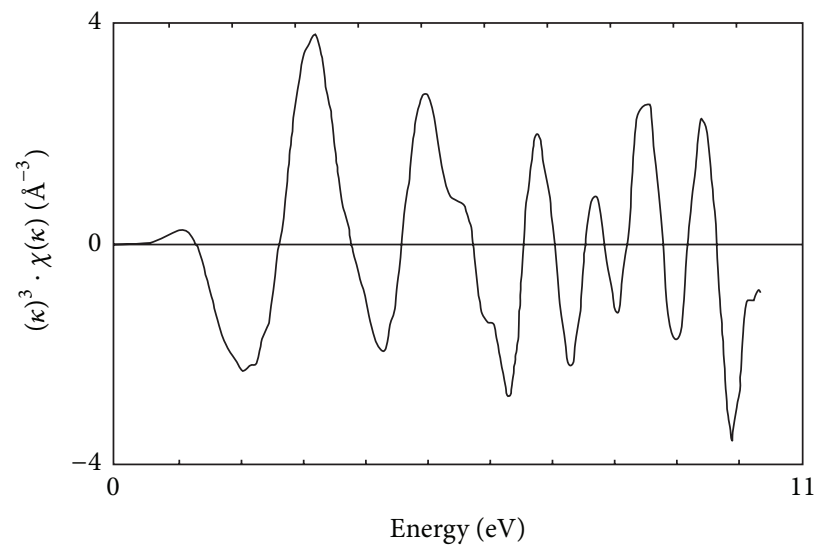

(a)

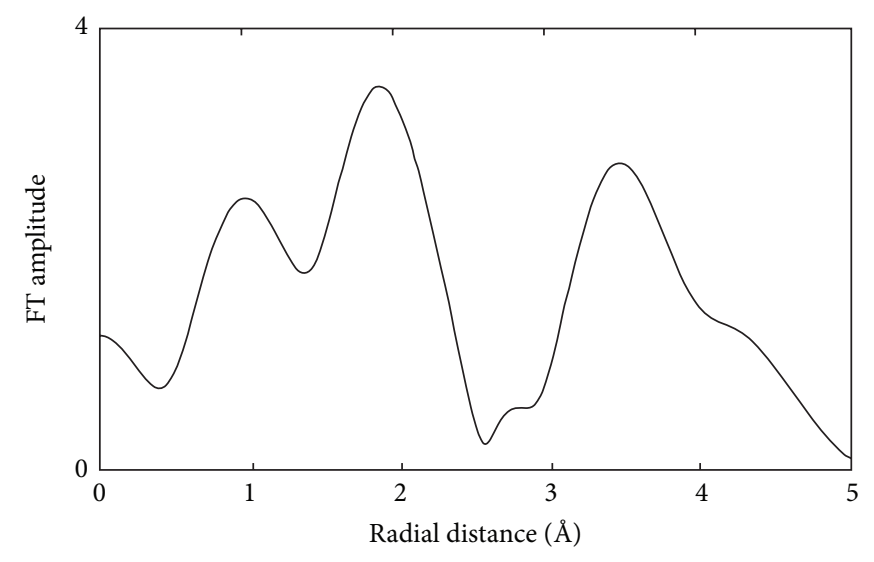

(b)

Figure 4: (a) Complex 2-edge EXAFS spectra in the form of $\kappa^{3} \cdot \chi(\kappa)$ of sample solution and its (b) Fourier transforms (uncorrected for the phase shift).

of 1,2 , and 3, each spectrum shows one singlet resonance for protons of $-\mathrm{C}\left(\mathrm{CH}_{3}\right)_{3}$. The ${ }^{1} \mathrm{H}-\mathrm{NMR}$ spectrum of complex 1 has a typical $A B$ pattern for the methylene bridge protons $\left(\mathrm{ArCH}_{2} \mathrm{Ar}\right)$ of the calixarene moiety which indicates that the compound exists in cone conformation [1]. The characteristic $\mathrm{AB}$ quartets of the bridging methylene protons of the ligand at 4.1 and $3.1 \mathrm{ppm}$ are found to shift to 4.3 and $3.5 \mathrm{ppm}$, respectively, which is an indication of metal complexation.

In the case of complex 2, a new signal appeared at chemical shift of $\delta=3.0$ (Table 3, complex 2) which was not observed in the parent ligand. The ${ }^{1} \mathrm{H}$-NMR spectrum of $\mathrm{Eu}(\mathrm{III})-\mathrm{H} 6 \mathrm{~L}$ complex in $\mathrm{CDCl}_{3}$ also showed doublets at 2.50 and 3.00 and one singlet at 4.00 [16]. The complex 3 showed one doublet at $\delta 4.3$ and 3.4 and one singlet at $\delta$ 3.00 for the bridging methane groups due to the different environments of the two hydrogen atoms on the methylene group. Through comparing the obtained spectra, while referring to the spectrum of the respective parent ligand, it is found that the resonances of methylene protons of $\mathbf{2}$ appeared as broad singlets, but the corresponding resonances of $\mathbf{1}$ and $\mathbf{3}$ split into clear pair doublets (Table 3). The splitting of the methylene resonances into pairs of doublets indicates that the calixarene ligands are rigid in solution at room temperature on the NMR timescale [1]. For $\mathbf{1}$ and 3, singlet resonances of $\mathrm{Ar}-\mathrm{H}$ are observed at $\delta=7.12$ and $7.14 \mathrm{ppm}$, respectively; for $\mathrm{Ar}-\mathrm{OH}$ these resonances are at $\delta=10.3$, respectively. Additionally, from the features of the peak for methylene protons it appears that a partial cone conformation is adopted by the calix[6] arene ligand $[22,25]$. For the three complexes, the chemical shifts related to DMF molecules are observed at $\delta=3.10$ for complex $\mathbf{1}$ and 2.57 for complex $\mathbf{2}$, respectively, suggestive of the involvement of DMF molecules in these complexes. Masuda et al. reported that the chemical shifts related to DMF molecules were observed at $\delta=$ 2.88, 2.95 and $8.01 \mathrm{ppm}$ for Sc-p-t-butylcalix[4,6,8]arenes complexes [26]. However, we did not observe such chemical shift at around $8.00 \mathrm{ppm}$ related to DMF for complex 3 . After careful comparison with the stoichiometry and properties of the previously studied $\mathrm{Ln}^{3+}$-calixarene complexes, it is concluded that the previous calixarenes do not exhibit the same complexation tendency towards $\mathrm{Ce}^{3+}$ as toward $\mathrm{Ln}^{3+}$. 
Moreover, it is important to note that $\mathrm{Ce}(\mathrm{III})$ is paramagnetic (one unpaired electron) and therefore in the proton NMR spectra paramagnetic shifts would be expected for the protons of any ligands coordinated to this ion. Lisowski and Mazurek reported such shifts for chiral macrocyclic La(III), $\mathrm{Ce}(\mathrm{III}), \operatorname{Pr}(\mathrm{III})$, and $\mathrm{Eu}(\mathrm{III})$ complex with chloride anions [27]. However, we have observed very little ${ }^{1} \mathrm{H}-\mathrm{NMR}$ shifts for $\mathrm{Ce}$ (III) complexes with nitrate anions. Engelhardt et al. [4] also observed little shifts for paramagnetic metal ioncalix $[n]$ arene complexes with nitrate anions.

3.6. EXFAS Spectra. Figures 4(a) and 4(b) show complex 2edge EXAFS spectra in the form of $\kappa^{3} \cdot \chi(\kappa)$ of sample solution and their Fourier transforms (uncorrected for the phase shift), respectively. The structure parameters of complexes in the first coordination sphere were determined by a curve fitting in the $k$ space. The Fourier filtering was performed over the $r$ range to include the main peak in the $|F(r)|$ curve for each sample. A least-squares calculation was then applied to the filtered $\kappa^{3} \cdot \chi(\kappa)$ values over the range $5.0<\kappa / 10^{-2} \mathrm{pm}^{-1}<9.2$ for the Ce K-edge spectra. The bond length, the Debye-Waller factor, and the coordination number of the complexes were then refined as independent variables by adopting the $\lambda$ value and the phase function evaluated. It has been reported that the structure of $\mathrm{p}$ - $\mathrm{t}$ butylcalix $[n]$ arenes is hardly affected by the metal substitution reaction, because of the rigid and stable structure of the ligand [1]. However, the bond lengths of the $\mathrm{Ce}^{3+}-\mathrm{p}-\mathrm{t}-$ butylcalixarene complexes depended on the composition of solution or coordinated atom.

The $\kappa^{3} \cdot \chi(\kappa)$ values of $\mathrm{Ce}^{3+}$-p-tert-butylcalix[6] arene complex solution were well reproduced considering two distinct peaks ascribed to $\mathrm{Ce}-\mathrm{O}(2.05 \AA)$ and $\mathrm{Ce}-\mathrm{Ce}(3.71 \AA)$ bondings in the Fourier transforms of the EXAFS spectrum [28]. Obviously, the position of $\mathrm{Ce}-\mathrm{O}$ bonding of the complex 2 sample was the same as that of pure cerium oxide [28]. After the formation of Ce-O bridge, the $\mathrm{Ce}$ (III) atoms of both ends are coordinated by phenol oxygen atoms of the ligand. There might be another possibility that each $\mathrm{Ce}$ (III) atom is coordinated by some oxygen atoms of water molecules. The $\mathrm{Ce}-\mathrm{O}\left(\mathrm{H}_{2} \mathrm{O}\right)$ bond length is $1.97 \AA$ as shown in Figure 4(a).

\section{Conclusions}

Three new $\mathrm{Ce}^{3+}$ with p-tert-butylcalix $[n]$ arene complexes $(n=4,6,8)$ were synthesized with parent calix $[n]$ arenes in a DMF solution of $\mathrm{Ce}\left(\mathrm{NO}_{3}\right)_{3} \cdot 6 \mathrm{H}_{2} \mathrm{O}$. Similarities among the three complexes are apparent, such as solubility in xylene, although the computed molar extinction coefficients of complex 2 showed the highest value. The complexing properties of the three compounds have been studied by means of FTIR, ${ }^{1} \mathrm{H}-\mathrm{NMR}$, and EXAFS and work is in progress to characterize the $\mathrm{Ce}^{3+}$-p-tert-butylcalix $[n]$ arene complexes by their X-ray structure. The synthesis of $\mathbf{1}, \mathbf{2}$, and 3 further reinforces the ideas that large polyalkoxide ligands, such as calixarenes, are appropriate for the design of new metal complex architectures and that a rich chemistry can be built at the boundary between macrocyclic, supramolecular, and coordination chemistries.

\section{Conflict of Interests}

The author declares no possible conflict of interests.

\section{Acknowledgments}

The author would like to acknowledge the support provided by King Abdulaziz City for Science and Technology (KACST) through the Science \& Technology Unit at King Fahd University of Petroleum \& Minerals (KFUPM) for funding this work through project no. 10-ADV1367-04 as part of the National Science, Technology and Innovation Plan. The author is grateful to Professor Yoshitaka Masuda (Kobe University, Japan) for his suggestions.

\section{References}

[1] C. D. Gutsche, in Monographs in Supramolecular Chemistry, J. F. Stoddart, Ed., vol. 1, p. 78, The Royal Society of Chemistry, Cambridge, 1989.

[2] A. Ikeda and S. Shinkai, "Novel cavity design using calix $[n]$ arene skeletons: toward molecular recognition and metal binding," Chemical Reviews, vol. 97, no. 5, pp. 1713-1734, 1997.

[3] C. Wieser, C. B. Dieleman, and D. Matt, "Calixarene and resorcinarene ligands in transition metal chemistry," Coordination Chemistry Reviews, vol. 165, pp. 93-161, 1997.

[4] L. M. Engelhardt, B. M. Furphy, J. M. D. Harrowfield, L. Kepert, A. H. White, and F. R. Wilner, "Coordination chemistry of the calixarenes. II. Europium(III) and p-t-butyl calix[6]arene," Australian Journal of Chemistry, vol. 41, no. 9, pp. 1465-1476, 1988.

[5] P. Thueéry, M. Lance, and M. Nierlich, "Crystal structure of an uranyl/p-tert-butyl calix[6]arene dimer," Supramolecular Chemistry, vol. 7, pp. 183-185, 1996.

[6] P. C. Leverd, P. Berthault, M. Lance, and M. Nierlich, "Caesium control of the coordination chemistry of tBu-calix[6]arene towards uranyl," European Journal of Inorganic Chemistry, no. 12, pp. 1859-1862, 1998.

[7] G. E. Hofmeister, E. Alvardo, J. A. Leary, D. I. Yoon, and S. F. Pedersen, "Synthesis and characterization of dimetallacalix[8]arene complexes," Journal of the American Chemical Society, vol. 112, pp. 8843-8851, 1990.

[8] M. M. Olmstead, G. Sigel, H. Hope, X. Xu, and P. P. Power, "Metallocalixarenes: syntheses and X-ray crystal structures of titanium(IV), iron(III), and cobalt(II) complexes of p-tertbutylcalix[4]arene," Journal of the American Chemical Society, vol. 107, pp. 8087-8091, 1985.

[9] R. N. Armstrong, "Glutathione S-transferases: structure and mechanism of an archetypical detoxication enzyme," Advances in Enzymology and Related Areas of Molecular Biology, vol. 69, pp. 1-44, 1994.

[10] B. M. Furphy, J. M. Harrowfield, D. L. Kepert, B. W. Skelton, A. H. White, and F. R. Wilner, "Bimetallic lanthanide complexes of the calixarenes: europium(III) and tert-butylcalix[8]arene," Inorganic Chemistry, vol. 26, no. 25, pp. 4231-4236, 1987. 
[11] N. P. Thuéry, M. Nierlich, J. Harrowfield, and M. Ogden, in Calixarene, Z. Asfari, V. Böhmer, J. Harrowfield, and J. Vicens, Eds., Kluwer Academic, Dodrecht, The Netherlands, 2001.

[12] S. R. Izatt, R. T. Hawkins, J. J. Christensen, and R. M. Izatt, "Cation transport from multiple alkali cation mixtures using a liquid membrane system containing a series of calixarene carriers," Journal of the American Chemical Society, vol. 107, no. 1, pp. 63-66, 1985.

[13] J. C. G. Bünzil, P. Froidevaux, and J. M. Harrowfield, "Complexes of lanthanoid salts with macrocyclic ligands. 41. Photophysical properties of lanthanide dinuclear complexes with ptert-butylcalix[8] arene," Inorganic Chemistry, vol. 32, pp. 33063311, 1993.

[14] J. M. Harrowfield, M. I. Ogden, and A. H. White, "Actinide complexes of the calixarenes. Part 2. Synthesis and crystal structure of a novel thorium(IV) complex of p-tert-butylcalix[8]arene," Journal of the Chemical Society, Dalton Transactions, vol. 10, pp. 2625-2632, 1991.

[15] H. M. Chawla, U. Hooda, and V. Singh, "Oxidation of simple phenols by a homobimetallic cerium(IV)-calix(8)arene complex in conjunction with hydrogen peroxide," Journal of the Chemical Society, Chemical Communications, vol. 5, pp. 617-618, 1994.

[16] L. M. Engelhardt, B. M. Furthy, J. M. Harrowfield, D. L. Kepert, B. W. Skelton, and A. H. White, "Coordination chemistry of the calixarenes. II. Europium(III) and p-t-Butyl calix[6]arene," Australian Journal of Chemistry, vol. 41, pp. 1465-1476, 1988.

[17] E. Weber, R. Haase, R. Pollex, and M. Czugler, "Preorganized macrocyclic receptors featuring endo-carboxylic Acid Groups. Host synthesis and inclusion compounds with alcohol and amine guests," Journal fur Praktische Chemie-Chemiker-Zeitung, vol. 341, pp. 274-283, 1999.

[18] P. D. Beer, P. A. Gale, and G. Z. Chen, "Mechanisms of electrochemical recognition of cations, anions and neutral guest species by redox-active receptor molecules," Coordination Chemistry Reviews, vol. 185-186, pp. 3-36, 1999.

[19] A. F. D. Namor, R. M. Cleverley, and M. L. Zapata-Ormachea, "Thermodynamics of calixarene chemistry," Chemical Reviews, vol. 98, no. 7, pp. 2495-2525, 1998.

[20] Y. Zhang, Y. Chunhus, and Y. Masuda, "Synthesis and Characterization of tetravalent cerium complexes with p-Tertbutylcalix $[n]$ arenes $(n=4,6,8)$," Journal of Rare Earths, vol. 20, pp. 41-46, 2002.

[21] Z. Marczenko, Spectrophotometric Determination of Elements, John Wiley \& Sons, New York, NY, USA, 1976.

[22] C. D. Gutsche, B. Dhawan, K. H. No, and R. Muthukrishnan, "Calixarenes. 4. The synthesis, characterization, and properties of the calixarenes from p-tert-butylphenol," Journal of the American Chemical Society, vol. 103, pp. 3782-3792, 1981.

[23] M. I. Ogden, [Ph.D. thesis], Department of Chemistry, University of Western Australia, 1991.

[24] S. W. Keller, G. M. Schuster, and F. L. Tobiason, "Conformational analysis of phenolic oligomers using Fourierransform transform infrared-spectroscopy-the para-transbutyl-calixarenes," Polymeric Materials: Science and Engineering, vol. 57, pp. 906-910, 1987.

[25] C. D. Gutsche and L. J. Bauer, "Calixarenes. 5. Dynamic NMR characteristics of p-tert-butylcalix[4]-arene and p-tertbutylcalix[8]arene," Tetrahedron Letters, vol. 22, no. 48, pp. 4763-4766, 1981.
[26] Y. Masuda, Y. Zhang, C. Yan, and B. Li, "Synthesis and characterization of scandium(III) complexes with p-tertbutylcalix $[n]$ arene $(n=4,6,8)$," Journal of Alloys and Compounds, vol. 872, pp. 275-277, 1998.

[27] J. Lisowski and J. Mazurek, "Chiral macrocyclic La(III), Ce(III), $\operatorname{Pr}(\mathrm{III})$ and $\mathrm{Eu}(\mathrm{III})$ complexes with chloride anions," Polyhedron, vol. 21, no. 8, pp. 811-816, 2002.

[28] A. V. Chadwick and S. L. P. Savin, "EXAFS study of nanocrystalline $\mathrm{CeO}_{2}$ samples prepared by sol-gel and ball-milling routes," Journal of Alloys and Compounds, vol. 488, no. 1, pp. 1-4, 2009. 

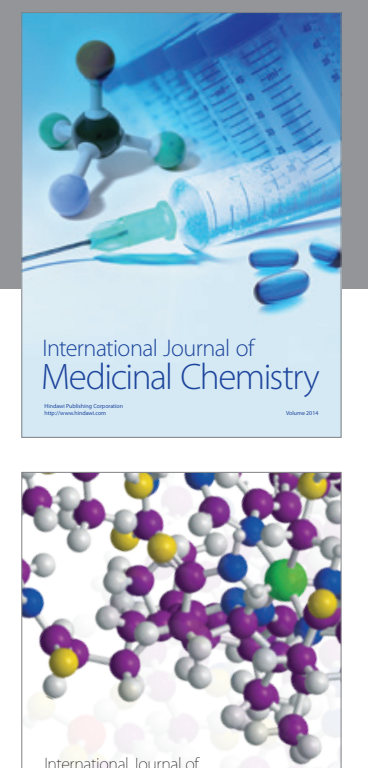

\section{Carbohydrate} Chemistry

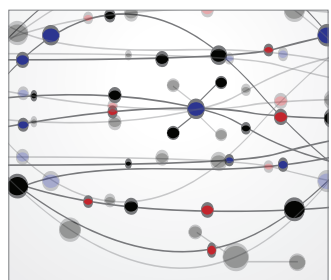

The Scientific World Journal
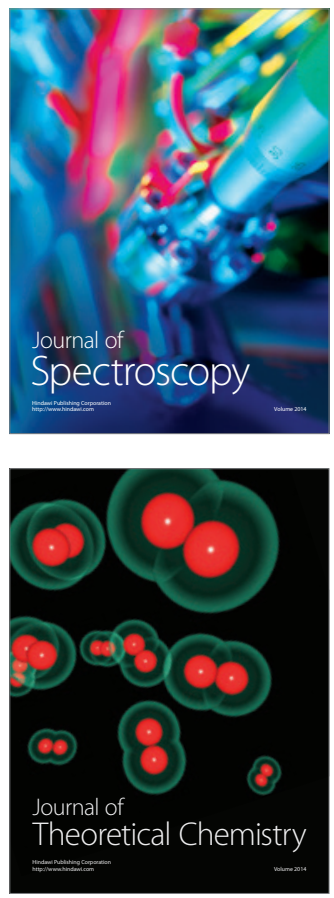
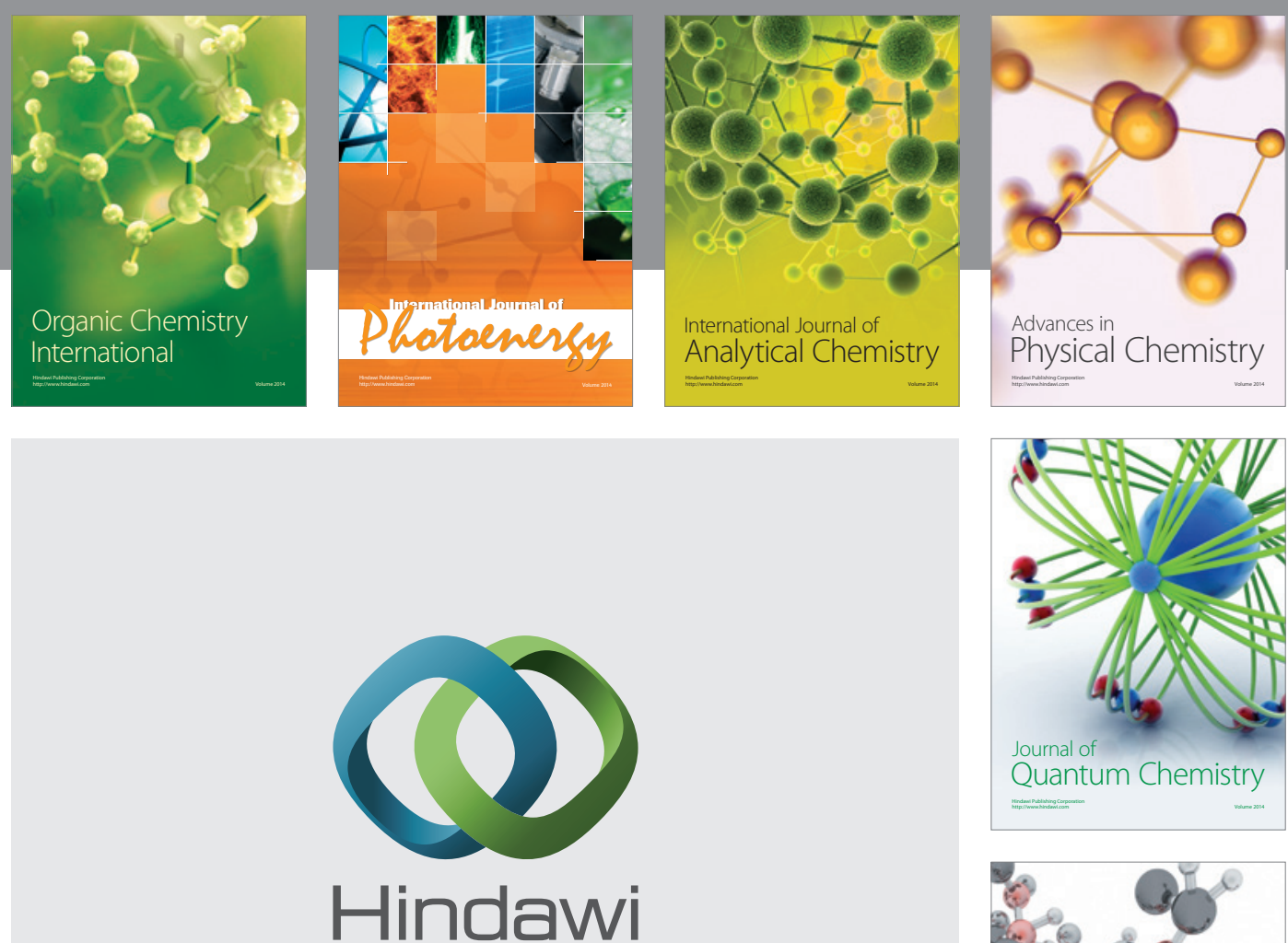

Submit your manuscripts at

http://www.hindawi.com

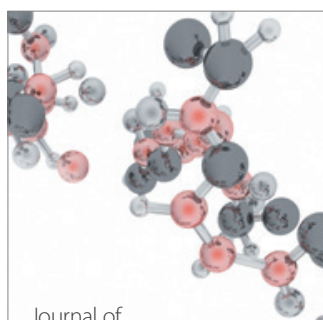

Analytical Methods

in Chemistry

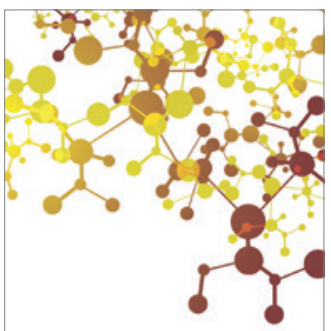

Journal of

Applied Chemistry

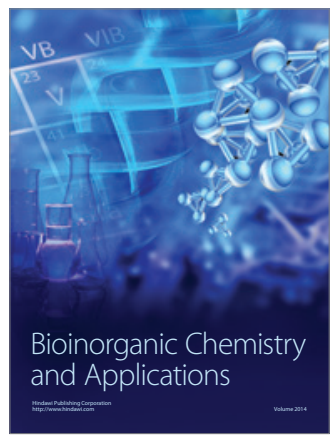

Inorganic Chemistry
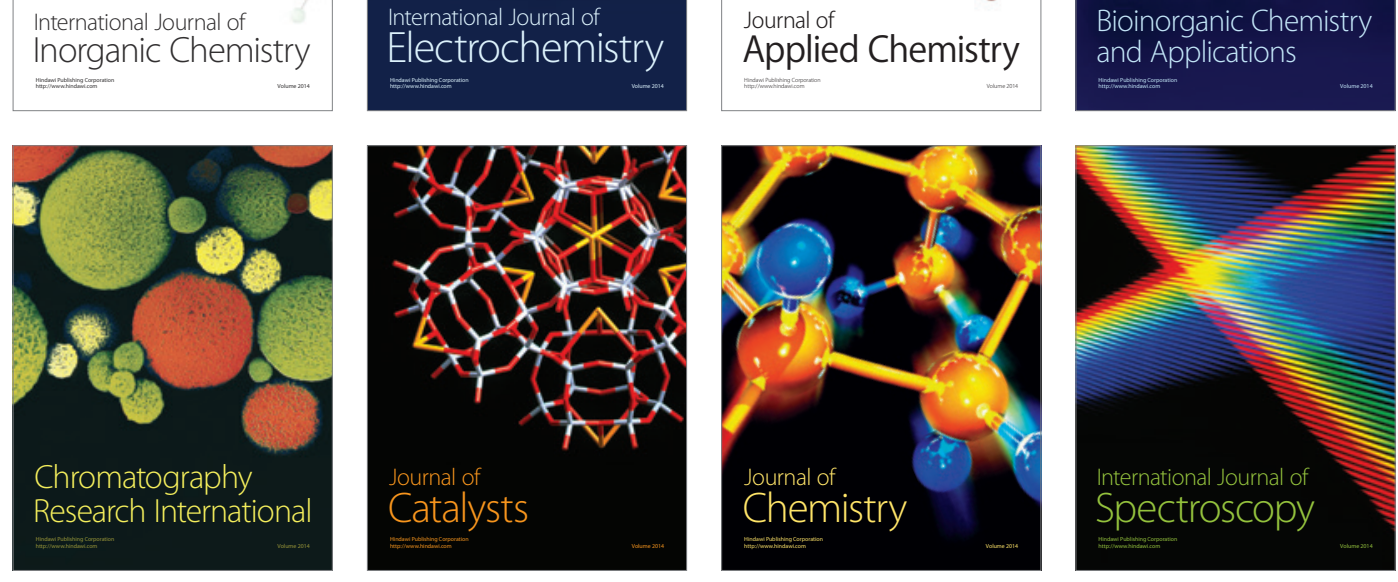